This Accepted Author Manuscript is copyrighted and published by Elsevier. It is posted here by agreement between Elsevier and University of Brasilia. Changes resulting from the publishing process - such as editing, corrections, structural formatting, and other quality control mechanisms - may not be reflected in this version of the text. The definitive version of the text was subsequently published in [Animal Reproduction Science, Volume 97, Issue 3-4, February 2007, Pages 237-245, doi:10.1016/j.anireprosci.2006.01.014].You may download, copy and otherwise use the AAM for non-commercial purposes provided that your license is limited by the following restrictions:

(1) You may use this AAM for non-commercial purposes only under the terms of the CC-BY-NCND license.

(2) The integrity of the work and identification of the author, copyright owner, and publisher must be preserved in any copy.

(3) You must attribute this AAM in the following format: [agreed attribution language, including link to CC BY-NC-ND license + Digital Object Identifier link to the published journal article on Elsevier's ScienceDirect ${ }^{\circledR}$ platform].

Este Manuscrito do Autor Aceito para Publicação (AAM) é protegido por direitos autorais e publicado pela Elsevier. Ele esta disponível neste Repositório, por acordo entre a Elsevier e a Universidade de Brasília. As alterações decorrentes do processo de publicação - como a edição, correção, formatação estrutural, e outros mecanismos de controle de qualidade - não estão refletidas nesta versão do texto. A versão definitiva do texto foi posteriormente publicado em [Animal Reproduction Science, Volume 97, Número 3-4, Fevereiro 2007, Páginas 237-245 doi:10.1016/j.anireprosci.2006.01.014]. Você pode baixar, copiar e utilizar de outra forma o AAM para fins não comerciais, desde que sua licença seja limitada pelas seguintes restrições:

(1) Você pode usar este AAM para fins não comerciais apenas sob os termos da licença CC- BYNC-ND.

(2) A integridade do trabalho e identificação do autor, detentor dos direitos autorais e editor deve ser preservado em qualquer cópia.

(3) Tem de atribuir este AAM no seguinte formato: [acordo na linguagem atribuída, incluindo o link para CC BY-NC-ND licença Digital + DOI do artigo publicado na revista Elsevier ScienceDirect ${ }^{\circledR}$ da plataforma]. 


\title{
Effects of chronic exposure to soy meal containing diet or soy derived isoflavones supplement on semen production and reproductive system of male rabbits
}

Julio Roquete Cardoso

Sonia Nair Báo

\begin{abstract}
Soy and derivative diets deliver large doses of isoflavones to human and animals throughout their lifespan, including gestation. Epidemiologic and experimental data suggest that the consumption of soybean containing foods may protect against cardiovascular disease and decrease breast, prostate and endometrial cancer risk. Based on animal and in vitro studies, however, concerns have been raised that consumption of isoflavones may cause potential adverse effects on the reproductive tract and behavior. The aim of this study was to investigate the effects of chronic consumption of a soy meal containing diet or soy isoflavones supplement on the morphology of reproductive organs, semen quality, age that males reached puberty, and sexual behavior of male rabbits. With this purpose, 16 female rabbits were randomly assigned to receive: (1) a soy- and alfafa-free diet; (2) a soy- and alfafa-free diet supplemented with $5 \mathrm{mg} / \mathrm{kg}$ body wt./day of soy isoflavones; (3) a soy- and alfafa-free diet supplemented with $20 \mathrm{mg} / \mathrm{kg}$ body wt./day of soy isoflavones; (4) a diet containing $18 \%$ of soy meal, throughout the gestation and lactation. After weaning, male offspring received the same diet, which was given to the respective mother. The age that males reached puberty, semen characteristics and sexual behavior were evaluated in these animals. At 33 weeks of age, the reproductive organs were submitted to histological evaluation. Rabbits, which received large amounts of isoflavones ( $20 \mathrm{mg} / \mathrm{kg}$ body wt./day) had a lesser food intake, body weight and semen volume. Spermatogenesis, morphology of male genital organs and sexual behavior did not differ significantly from the control group. We conclude that chronic dietary treatment with soy based diet or soy isoflavones have no adverse effects on the observed reproductive patterns of male rabbits.
\end{abstract}

Keywords: Phytoestrogens; Isoflavones; Soy; Reproduction; Rabbits

\section{Introduction}

Phytoestrogens (PE) are estrogenic compounds found in plants (Kurzer and Xu, 1997). They can be divided into three main classes: isoflavones (derived principally from soybeans and clover), coumestans (derived from sprouting plants, like alfafa) and lignans (found in flaxseed). In the isoflavone group, genistein and daidzein are thought to exert the most potent estrogenic hormone activity, and thus, most of the research efforts have been directed toward these molecules (Lephart et al., 2002). 
Soy meal is a protein source commonly used and is commercially available for laboratory and farm animal diets, therefore, animals ingesting these diets are continually exposed to these hormonally active compounds (Lephart et al., 2002). Serum isoflavone concentrations exceeding the endogenous estrogen concentrations by $30,000-60,000$-fold were observed in rodents fed commercial rodent diets (Brown and Setchell, 2001). The newborn rat pups showed about $25 \%$ of maternal isoflavone concentrations that were maintained throughout the suckling period.

Diets of other animal species contain large amounts of PE such as those detected in commercial chow of cats (Setchell et al., 1987 and Court and Freeman, 2002), dogs (Cerundolo et al., 2004) and rodents (Thigpen et al., 1999, Brown and Setchell, 2001 and Degen et al., 2002) with the protein source being soy meal. These findings indicate that all investigators should be vigilant to the PE composition of laboratory animal diets because these agents might have a direct effect on the outcome of bioassays designed to detect developmental toxicity or carcinogenicity (Casanova et al., 1999, Thigpen et al., 1999 and Brown and Setchell, 2001).

There are few reports in literature regarding the effects of plant estrogens on reproductive health in males (Strauss et al., 1998, Mitchell et al., 2001 and Faqi et al., 2004), especially in breeding or livestock animals. This is the first study to examine the effects of chronic dietary treatment with soy isoflavones on the reproductive tract of male rabbits.

The aim of the present study was to investigate the effects of the chronic dietary treatment with soy containing components or soy isoflavone supplements on: (1) morphology of the reproductive organs; (2) semen quality; (3) age of puberty; (4) sexual behavior of male rabbits.

\section{Materials and methods}

\subsection{Animals}

Prior to study initiation, the experimental protocol was reviewed and approved by the University of Brasília Institute of Biological Sciences Ethical Committee to Animal Use. One male New Zealand and 16 female rabbits between 8 and 10 months of age were housed individually in steel cages equipped with automatic watering systems. Animals were kept on natural photoperiod and environmental temperature. 


\subsection{Treatments}

Does were randomly divided into four equal groups of four rabbits each. Each group was subjected to one of the following treatments: (1) soy and alfafa free diet (S-); (2) soy and alfafa free diet supplemented with $5 \mathrm{mg} / \mathrm{kg}$ body wt./day of soy isoflavones (ISF 05); (3) soy and alfafa free diet supplemented with $20 \mathrm{mg} / \mathrm{kg}$ body wt./day of soy isoflavones (ISF 20) (Soy Isoflavones, 40\%, DEG Importação de Produtos Químicos Ltda, São Paulo, SP); and (4) diet containing $18 \%$ of soy meal $(\mathrm{S}+)$. Based on data from compendiums of isoflavone content in soybean-based foods (Reinli and Block, 1996), this diet provided about $13 \mathrm{mg} / \mathrm{kg}$ body wt./day of isoflavones.

The animals of other groups received similar portions of corn starch as placebo. The proper dose of isoflavones as well as placebo was inserted directly into the oral cavity after rabbit immobilization. The four groups received water and food ad libitum.

The diets (Nutrimais Rações ${ }^{\circledR}$, Uberlândia, MG) contained similar nutritional amounts of other nutrients, but the protein source used in S- and ISF treatments was cottonseed meal. The diet used in the treatment $4(\mathrm{~S}+)$ is a commercially available diet, similar to other diets commonly employed in rabbit feeding. The bromatological analyses to verify the nutritional values of the diets were assayed by Food Analysis Laboratory of UPIS (Brasília, Brazil).

The dams were mated with the same buck. At the 5th week of post birth, male offspring were numbered and surplus pups were randomly excluded from the study. The other 10 pups of each treatment received the same treatments from weaning (5 weeks) to 33 weeks of age. These animals were thus subjected to gestational, lactational, and post-lactational diets containing the various amounts of soy isoflavones.

Throughout the dietary treatment period, all animals were monitored daily for health status. Body weights and food consumption were measured weekly throughout the experimental period.

\subsection{Ejaculates collection and evaluation}

The artificial vagina (AV) for semen collection was built of polyvinyl chlorete conduit (45 mm length, $15 \mathrm{~mm}$ diameter and $2 \mathrm{~mm}$ thickness), rubber condom for human semen 
collection (Microtex, INAL, Jaboticabal, SP, Brazil), two rubber bands, and a graduated collector tube. For the AV mounting, the blind sack of the condom was removed; its edges were folded over the borders of the rigid tube and attached by means of the rubber bands. Before the attachment of the second edge, the space between the rigid (external) and flexible (internal) tubes was filled with warm water $\left(60^{\circ} \mathrm{C}\right)$. The $A V$ was always used just when inner temperature fell between 45 and $50{ }^{\circ} \mathrm{C}$ (Andrade et al., 2002). The collection tube was attached onto one of the edges, and the free edge was positioned to penis intromission. Before semen collection, bucks were allowed one false mount and at the subsequent mounting, the AV was adequately positioned for penis intromission. Bucks adapted easily to this routine and no refusals occurred.

From 100 to 170 days of age, semen samples were collected once a week to evaluate sexual maturation. After this initial period, the animals were collected every other day for 5 weeks, a total of 17 collections. The first seven samples were used to stabilize sperm output and were not included in the analysis, so the daily sperm output was quantified using the last 10 ejaculates.

After removing and weighing the gel mass, ejaculate volume was recorded in a graduated tube attached to the artificial vagina. Immediately after ejaculation, a semen and a saline drop was mixed on a heated $\left(37^{\circ} \mathrm{C}\right)$ slide under a cover slip for sperm motility (0-100\%) and vigor (0-5) evaluation (light microscope, 400x). For determination of sperm concentration, ejaculates were diluted $1: 100$ in a $4 \%$ formol/0.9\% saline solution and counted twice in Neubauer haemocytometer slide (GmbH + Co., Brandstwiete 4, 2000 Hamburg 11, Germany) using a light microscope (400x). The sperm morphology was examined on slides stained with Congo red and Gentian violet solutions.

\subsection{Age that males reached puberty}

The age at puberty was considered when semen characteristics reached concurrently the following values: sperm concentration over $75 \times 106 \mathrm{sperm} / \mathrm{ml}$, overall motility over $50 \%$ and vigor of motile sperm over 2.5. These values were established for the present study. The ages (in days), which males showed ejaculates within these values were used for data analysis. 


\subsection{Sexual behavior}

For sexual behavior analysis, measurements for time of reaction (latency to begin mounting); the interval between two consecutive ejaculations into the artificial vagina; and the mounting reflex were taken.

The mounting reflex as indicative of manifestation of sexual interest was considered when rabbits were capable of mounting and completing copulation, even if mature semen characteristics were not present. The ages (in days), which males exhibited the mounting reflex were used for data analysis.

The time of reaction was recorded from the time of subjecting a doe to the buck and mounting; it was measured in seconds using a stopwatch. The interval between two consecutive ejaculations into the artificial vagina was also measured (in seconds) after the analysis period was concluded. Values significantly greater or lesser than those from the control group indicate decreased or increased libido, respectively.

\subsection{Tissue collection and evaluation}

At $230( \pm 3)$ days of age, males were killed via jugular exsanguination, after barbiturate anesthesia. Testes, epididymides, proprostate and prostate glands were dissected and weighed. For histopathological evaluation, organ fragments were fixed in Bouin's solution followed by dehydratation in $50 \%$ and $70 \%$ ethanol. After fixation, the tissue fragments were embedded in paraffin, sectioned at $5 \mu \mathrm{M}$ in size and stained with hematoxylin and eosin. The sections were carefully examined for the presence of abnormalities.

\subsection{Statistical methods}

Comparisons between S+ and S- (control) groups were performed using analysis of variance (ANOVA), as all data had normal distribution. Comparisons among ISF 05, ISF20 and S- (control) groups were made using ANOVA (also data had normal distribution); when statistically significant $(P<0.05)$ intergroup differences were identified by ANOVA, post hoc 
analysis were assessed using a means test (Tukey's test). Values were expressed as mean \pm S.E.M. Statistical analyses were carried out using the Statistical Analysis System Software (version 8.2; 1999).

\section{Results}

\subsection{Health and growth evaluations}

Chronic dietary treatment with soy based diet or soy isoflavones in rabbits induced no mortality or evidence of gross toxicity that was identifiable by clinical or physical observations.

\subsection{Effects of chronic dietary treatment with soy-based diet or isoflavone supplements}

\subsubsection{Age that males reached puberty}

The sexual maturation of the bucks occurred at ages compatible with breed standards and regional bioclimatological conditions, however, data indicated that soy meal-dietary treatment of rabbits resulted in more precocious males as compared with the control (S-) group $(145.2 \pm 2.1 \mathrm{~S}-; 131.6 \pm 2.0$ days of age $\mathrm{S}+$; $\mathrm{P}<0.05)$. There were no significant differences among ISF 05 (138.5 \pm 1.7$)$, ISF 20 (139.7 \pm 1.3$)$ and S- (145.2 \pm 2.1 days of age) groups.

\subsubsection{Semen quality}

To reduce the influence of other variables, results of the semen characteristics among the treatments were based on data obtained from the evaluation of 400 semen samples. The values are summarized in Table 1. Rabbits in the ISF 20 group had smaller semen volume than rabbits in the $\mathrm{S}-$ (control) group $(\mathrm{P}<0.01)$. Ejaculate semen volume of the animals in the $(\mathrm{S}+)$ or ISF 5 groups did not differ significantly from that of animals in the S- group. Although sperm concentration was found to be greater in the ISF 20 than in the S-group, daily sperm output (DSO) did not statistically differ from the S- group ( Fig. 1, Table 1). The percentage of motile 
sperm did not differ significantly from S-, but sperm vigor was improved in rabbits with isoflavone treatment at $20 \mathrm{mg} / \mathrm{kg}$ body wt./day $(\mathrm{P}<0.01)$. The percentage of abnormal sperm was less in the semen samples of the ISF 20 group $(P<0.05)$.

Table 1

Effects of soy meal containing diet $(\mathrm{S}+)$ or soy isoflavones supplement $(05$ and $20 \mathrm{mg} / \mathrm{kg}$ BW/day) on semen characteristics of rabbits

\begin{tabular}{lcrrr}
\hline Variable & S- (Control) & \multicolumn{1}{c}{ ISF 05 } & \multicolumn{1}{c}{ ISF 20 } & \multicolumn{1}{c}{ S+ } \\
\hline Volume (ml) & $0.54 \pm 0.0 \mathrm{a}$ & $0.48 \pm 0.0 \mathrm{ab}$ & $0.44 \pm 0.0 \mathrm{~b}$ & $0.50 \pm 0.0 \mathrm{~ns}$ \\
Motility (\%) & $77.5 \pm 1.3 \mathrm{a}$ & $80.8 \pm 0.9 \mathrm{a}$ & $76.9 \pm 1.7 \mathrm{a}$ & $77.3 \pm 1.0 \mathrm{~ns}$ \\
Vigor $(0-5)$ & $3.1 \pm 0.1 \mathrm{~b}$ & $3.1 \pm 0.1 \mathrm{~b}$ & $3.4 \pm 0.0 \mathrm{a}$ & $3.1 \pm 0.0 \mathrm{~ns}$ \\
Abnormal sperm $(\%)$ & $25.3 \pm 1.2 \mathrm{a}$ & $23.3 \pm 1.0 \mathrm{ab}$ & $21.2 \pm 1.2 \mathrm{~b}$ & $23.3 \pm 1.6 \mathrm{~ns}$ \\
Sperm concentration $\left(\times 10^{6} / \mathrm{ml}\right)$ & $197.1 \pm 11.2 \mathrm{~b}$ & $208.3 \pm 5.2 \mathrm{ab}$ & $237.8 \pm 9.6 \mathrm{a}$ & $227.5 \pm 15.0 \mathrm{~ns}$ \\
Daily sperm output DSO $\left(\times 10^{6}\right)$ & $104.7 \pm 5.0 \mathrm{a}$ & $99.9 \pm 1.6 \mathrm{a}$ & $104.6 \pm 5.0 \mathrm{a}$ & $113.7 \pm 7.3 \mathrm{~ns}$ \\
\hline
\end{tabular}

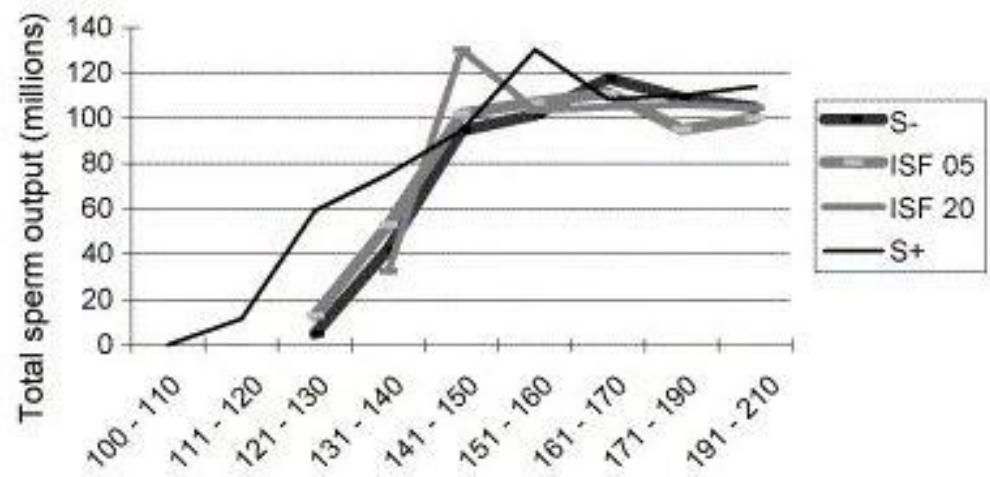

Age (days)

Fig. 1. Sperm production in rabbits fed soy meal containing diet $(\mathrm{S}+)$, supplemented with soy-derived

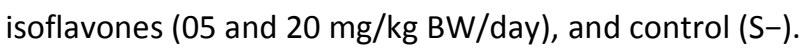

\subsubsection{Reproductive organ weight and morphology}

At $230( \pm 3)$ days of age, rabbits were killed as previously described and the reproductive organs were dissected and weighed. Rabbits with diets supplemented with isoflavones at the dose of $20 \mathrm{mg} / \mathrm{kg}$ body wt./day had a lesser body weight than those from ISF 05 and $S-$ groups $(P<0.01)$. The lesser body weight of the rabbits in the ISF 20 group was associated with lesser food intake $(P<0.05)$. Repeated analyzes of variance of food consumption and body weight values showed that these variables differed significantly from the control group from 13 and 17 weeks of age, respectively (data not shown). Differences in relative organs weight from the control group were not significant ( Table 2). 
Table 2.

Food intake, body and reproductive organs weight of rabbits fed soy meal containing diet (S+), or supplemented with soy isoflavones ( 5 and $20 \mathrm{mg} / \mathrm{kg} \mathrm{BW/day)}$

\begin{tabular}{lcccr}
\hline Variable & S- $($ Control) & ISF 05 & ISF 20 & S+ \\
\hline Body weight BW $(\mathrm{g})$ & $3754.4 \pm 56.73 \mathrm{a}$ & $3578.0 \pm 54.00 \mathrm{a}$ & $3340 \pm 39.21 \mathrm{~b}$ & $3912.5 \pm 52.80^{\circ}$ \\
Food intake $^{\mathrm{a}}(\mathrm{g})$ & $112.1 \pm 2.50 \mathrm{a}$ & $109.0 \pm 1.70 \mathrm{a}$ & $99.0 \pm 1.8 \mathrm{~b}$ & $119.2 \pm 2.00^{\circ}$ \\
Testes/BW $(\mathrm{mg} / \mathrm{g})_{\text {Epididymides/BW }(\mathrm{mg} / \mathrm{g})}$ & $1.53 \pm 0.02 \mathrm{a}$ & $1.55 \pm 0.01 \mathrm{a}$ & $1.57 \pm 0.04 \mathrm{a}$ & $1.50 \pm 0.01 \mathrm{~ns}$ \\
Prostate/BW $(\mathrm{mg} / \mathrm{g})$ & $0.205 \pm 0.01 \mathrm{a}$ & $0.63 \pm 0.00 \mathrm{a}$ & $0.63 \pm 0.01 \mathrm{a}$ & $0.57 \pm 0.01 \mathrm{~ns}$ \\
Proprostate/BW $(\mathrm{mg} / \mathrm{g})$ & $0.198 \pm 0.00 \mathrm{a}$ & $0.192 \pm 0.00 \mathrm{a}$ & $0.193 \pm 0.00 \mathrm{a}$ & $0.205 \pm 0.00 \mathrm{~ns}$ \\
\hline
\end{tabular}

Values are given as mean \pm S.E.M. of 10 ejaculates, $n=10$ /group. Rows with different letters differ significantly $(P<$ 0.05 ; Tukey's test). ns, Differences were not significant from $S-(P>0.05)$.

a Average values from 29 to 33 weeks of age.

* Statistically significant difference from S- $(P<0.05)$.

Histopathologic evaluation of the seminiferous tubules and intersticium of the testis did not identify any pattern of morphologic alterations that could be associated with the soy meal based or isoflavone diets (Fig. 2). The dynamics of the seminiferous epithelial cycle were clearly evident in all testes of this study, corroborating the in vivo findings. No evidence of pathological changes was observed in the epididymal duct of the caput, corpus, and cauda epididymides among the treatments. The efferent ductules as well as the initial segment of the deferent duct were not affected by the treatments. The epithelium of the pro-prostate and prostate acini was carefully examined for metaplastic changes because such alterations are often reported in estrogen-treated animals. However, long-term treatment with soy isoflavones or soy meal based diets failed to induce any pathological changes in the evaluated rabbit sex accessory glands.
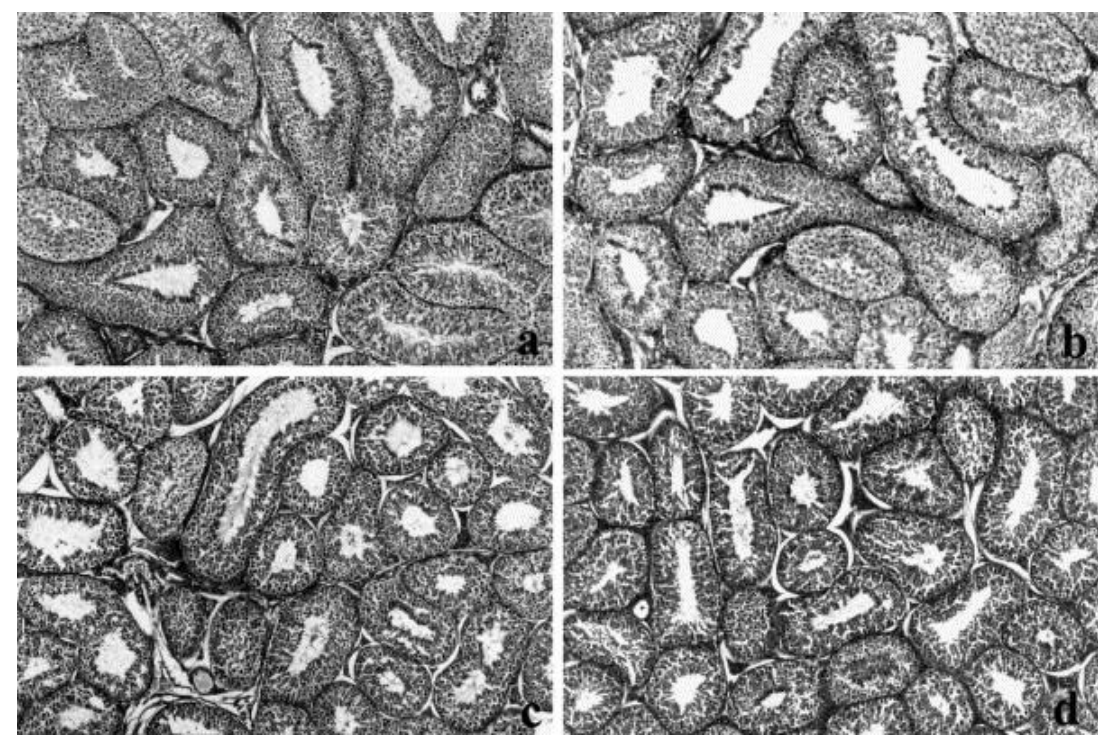

Fig. 2. Testis of rabbits fed soy meal containing diet (a), supplemented with $5 \mathrm{mg} / \mathrm{Kg} / \mathrm{BW} /$ day with soy isoflavones (b), supplemented with $20 \mathrm{mg} / \mathrm{kg} / \mathrm{BW} /$ day with soy isoflavones (c), and control (d). HE 100x. 


\subsection{Sexual behavior}

Analysis of variance did not reveal differences either in the age that males exhibited the mounting reflex or in the time of reaction in relation to males in the control group. The interval between two consecutive ejaculations into the artificial vagina was less $(P<0.01)$ in ISF 20 group, than ISF 05 and S- groups, but there was no difference between S+ and Sgroups ( Table 3). The data from the present study indicate that treatment with isoflavones did not adversely influence sexual behavior of the males.

Table 3

Effects of soy meal containing diet (S+) or soy isoflavones supplement $(05$ and $20 \mathrm{mg} / \mathrm{kg}$ $\mathrm{BW} /$ day) on the age that rabbits expressed mounting reflex, time of reaction, and interval between two consecutive ejaculations into the artificial vagina $(\Delta t)$

\begin{tabular}{lrrrr}
\hline Variable & S - (control) & \multicolumn{1}{c}{ ISF 05 } & \multicolumn{1}{c}{ ISF 20 } & \multicolumn{1}{c}{ S+ } \\
\hline Mounting reflex (days) & $123.0 \pm 2.0 \mathrm{a}$ & $119.3 \pm 2.8 \mathrm{a}$ & $124.5 \pm 3.5 \mathrm{a}$ & $118.0 \pm 2.6 \mathrm{~ns}$ \\
Time of reaction (s) & $3.7 \pm 0.2 \mathrm{a}$ & $4.0 \pm 0.3 \mathrm{a}$ & $3.9 \pm 0.2 \mathrm{a}$ & $3.6 \pm 0.3 \mathrm{~ns}$ \\
$\Delta t$ (s) & $97.0 \pm 2.4 \mathrm{a}$ & $92.6 \pm 1.8 \mathrm{a}$ & $79.0 \pm 1.9 \mathrm{~b}$ & $106.0 \pm 4.0 \mathrm{~ns}$ \\
\hline
\end{tabular}

Values are given as mean \pm S.E.M., $n=10$ /group. Rows with different letters differ significantly $(P<0.05$; Tukey's test). ns, Differences were not significant from $S-(P>0.05$; ANOVA).

\section{Discussion}

Despite reports about the potential effects of the PE verified in in vitro studies, in vivo assays have failed to induce major effects on the male reproductive tract. In this context, epididymal and testicular sperm counts were not altered in rats administered genistein orally at doses of $12.5-100 \mathrm{mg} / \mathrm{kg}$ on postnatal days $1-5$ (Nagao et al., 2001), 10-1000 $\mu \mathrm{g} / \mathrm{day}$ (Shibayama et al., 2001) or $100 \mu \mathrm{g} /$ day of coumestrol (Awoniyi et al., 1997). This was also true in rats chronically administered genistein at a dose of $50 \mu \mathrm{g} /$ day (Roberts et al., 2000), 0.1-10 $\mathrm{mg} / \mathrm{kg} /$ day through pregnancy and lactation (Fielden et al., 2003), 200 and $2000 \mathrm{mg}$ of genistein per $\mathrm{kg}$ of diet for 12 months (Faqi et al., 2004) or $2.5 \mathrm{mg} / \mathrm{kg} /$ day for 5 months (Lee et al., 2004). No influence was detected on semen quality in healthy men after supplementation daily for 2 months with soy protein containing $40 \mathrm{mg}$ of isoflavones (Mitchell et al., 2001). Interestingly, in rabbits, genistein caused the increase in sperm motility and concentration and alleviated the negative effects of cypermethrin on semen variables (Yousef et al., 2003). In agreement with these findings, no negative effects on male fertility were observed in the rabbits of this investigation after soy meal or soy isoflavone treatments. However, isoflavonecontaining diets significantly decreased semen volume when treatments were in greater 
amounts ( $20 \mathrm{mg} / \mathrm{kg}$ body wt./day) than those consumed by the dietary way. This fact resulted in an increase in sperm concentration, but sperm output (sperm concentration $\times$ semen volume) did not differ from the control. Therefore, exocrine testicular function seems to be normal.

Results of the present study demonstrated that testes weight and morphology are not influenced by chronic treatment with a soy meal or isoflavone supplemented diet. In addition, PE treatment did not induce alterations in testes weight of rats (Casanova et al., 1999, Roberts et al., 2000, Shibayama et al., 2001, Fielden et al., 2003, Ohno et al., 2003, Faqi et al., 2004 and Lee et al., 2004), rabbits (Yousef et al., 2003) and men (Mitchell et al., 2001).

Smaller body weight in isoflavone-treated rabbits was also reported in rats (Lephart et al., 2001 and Nagao et al., 2001), although investigators did not correlate this with food intake. The association with food intake observed in rabbits in the present study was also reported in Sprague-Dawley rats fed diets containing genistein (Casanova et al., 1999), suggesting a possible anorectic effect of PE on the central nervous system, similar to that of endogenous estrogens (Bonavera et al., 1994). This effect, however, seems to be associated with chronic treatment with to large amounts of soy isoflavones because dams did not have significant differences in food intake throughout the gestation and lactation periods (total of 9 weeks); and pups showed decreased food consumption just after 13 weeks of postnatal treatment (data no shown). Because there was no statistically significant difference between dietary controls and soy containing diet groups in body weight gain, there are no apparent detrimental impacts on animal health or well being.

In conclusion, soy meal as main source of protein in the diet of rabbits does not induce deleterious effects on sexual behavior or semen production. Considering this, soy meal can be used for feeding breeding rabbits. Also, normal dietary treatments with soy isoflavones did not cause toxic effects on the evaluated variables of males. However, these results cannot be extrapolated to females, which are admittedly more sensitive to the effect of environmental estrogens.

\section{Acknowledgments}

We would like to acknowledge the colleagues Dr. S. Vasconcelos, Dr. H. Blume and MSc R. G. Mondadori for critical reading of the manuscript and helpful discussion. UPIS, Faculdades Integradas (Brasília, DF) for the material and laboratorial support. Nutrimais rações (Uberlândia, MG) for the development of the specific diets used in this study. CAPES. 


\section{REFERENCES}

Andrade, A.F.C., Yonezawa, L.A., Celeghini, E.C.C., Spers, A., Arruda, R.P., 2002. Um novo modelo de vagina artificial para coelhos. Rev. Bras. Reprod. Anim. 26, 201-204.

Awoniyi, C.A., Roberts, D., Chandrashekar, V., Veeramachaneni, D.N., Hurst, B.S., Tucker, K.E., Schlaff, W.D., 1997. Neonatal exposure to coumestrol, a phytoestrogen, does not alter spermatogenic potential in rats. Endocrine 7 (3), 337-341.

Bonavera, J.J., Dube, M.G., Kalra, P.S., Kalra, S.P., 1994. Anorectic effects of estrogen may be mediated by decreased neuropeptide- $Y$ release in the hypothalamic paraventricular nucleus. Endocrinology 134 (6), 2367-2372.

Brown, N.M., Setchell, K.D.R., 2001. Animal models impacted by phytoestrogens in commercial chow: implications for pathways influenced by hormones. Lab. Invest. 81, 735-747.

Casanova, M., You, L., Gaido, K.W., Archibeque-Engle, S., Janszen, D.B., Heck, H.A., 1999. Developmental effects of dietary phytoestrogens in Sprague-Dawley rats and interactions of genistein and daidzein with rat estrogen receptors alpha and beta in vitro. Toxicol. Sci. 51 (2), 236-244.

Cerundolo, R., Court, M.H., Hao, Q., Michel, K.E., 2004. Identification and concentration of soy phytoestrogens in commercial dog foods. Am. J. Vet. Res. 65 (5), 592-596.

Court, M.H., Freeman, L.M., 2002. Identification and concentration of soy isoflavones in commercial cat foods. Am. J. Vet. Res. 63 (2), 181-185.

Degen, G.H., Janning, P., Diel, P., Bolt, H.M., 2002. Estrogenic isoflavones in rodent diets. Toxicol. Lett. 128, 145-157. Faqi, A.S., Johnson, W.D., Morrissey, R.L., Mc Cormick, D.L., 2004. Reproductive toxicity assessment of chronic dietary exposure to soy isoflavones in male rats. Reprod. Toxicol. 18 (4), 605-611.

Fielden, M.R., Samy, S.M., Chou, K.C., Zacharewski, T.R., 2003. Effect of human dietary exposure levels of genistein during gestation and lactation on long-term reproductive development and sperm quality in mice. Food. Chem. Toxicol. 41 (4), 447-454.

Kurzer, M.S., Xu, X., 1997. Dietary phitoestrogens. Rev. Nutr. 17, 353-381.

Lee, B.J., Kang, J.K., Jung, E.Y., Yun, Y.W., Baek, I.J., Yon, J.M., Lee, Y.B., Sohn, H.S., Lee, J.Y., Kim, K.S., Nam, S.Y., 2004. Exposure to genistein does not adversely affect the reproductive system in adult male mice adapted to a soy-based commercial diet. J. Vet. Sci. 5 (3), 227-234.

Lephart, E.D., Adlercreutz, H., Lund, T.D., 2001. Dietary soy phytoestrogen effects on brain structure and aromatase in Long-Evans rats. Neuroreport 12 (16), 3451-3455.

Lephart, E.D., West, T.W., Weber, K.S., Rhees, R.W., Setchell, K.D., Adlercreutz, H., Lund, T.D., 2002. Neurobehavioral effects of dietary soy phytoestrogens. Neurotoxicol. Teratol. 24 (1), 516. 
Mitchell, J.H., Cawood, E., Kinniburgh, D., Provan, A., Collins, A.R., Irvine, D.S., 2001. Effect of a phytoestrogen food supplement on reproductive health in normal males. Clin. Sci. 100, 613618.

Nagao, T., Yoshimura, S., Saito, Y., Nakagomi, M., Usumi, K., Ono, H., 2001. Reproductive effects in male and female rats of neonatal exposure to genistein. Reprod. Toxicol. 15 (4), 399411.

Ohno, S., Nakajima, Y., Inoue, K., Nakazawa, H., Nakajin, S., 2003. Genistein administration decreases serum corticosterone and testosterone levels in rats. Life Sci. 74 (6), 733-742.

Reinli, K., Block, G., 1996. Phytoestrogen content of foods-a compendium of literature values. Nutr. Cancer 26 (2), 123-148.

Roberts, D., Veeramachaneni, D.N., Schlaff, W.D., Awoniyi, C.A., 2000. Effects of chronic dietary exposure to genistein, a phytoestrogen, during various stages of development on reproductive hormones and spermatogenesis in rats. Endocrine 13 (3), 281-286.

Setchell, K.D.R., Gosselin, S.J., Welsh, M.B., Johnston, J.O., Balistreri, W.F., Kramer, L.W., Dresser, B.L., Tarr, M.J., 1987. Dietary estrogens-a problable cause of infertility and liver disease in captive Cheetahs. Gastroenterology 93, 225-233.

Shibayama, T., Fukata, H., Sakurai, K., Adachi, T., Komiyama, M., Iguchi, T., Mori, C., 2001. Neonatal exposure to genistein reduces expression of estrogen receptor alpha and androgen receptor in testes of adult mice. Endocrinol. J. 48 (6), 655-663.

Strauss, L., Makela, S., Joshi, S., Huhtaniemi, I., Santti, R., 1998. Genistein exerts estrogen-like effects in male mouse reproductive tract. Mol. Cell. Endocrinol. 144, 83-93.

Thigpen, J.E., Setchell, K.D., Ahlmark, K.B., Locklear, J., Spahr, T., 1999. Phytoestrogen content of purified open- and closed-formula laboratory animal diets. Lab. Anim. Sci. 49 (5), 530-536.

Yousef, M.I., El-Demerdash, F.M., Al-Salhen, K.S., 2003. Protective role of isoflavones against the toxic effect of cypermethrin on semen quality and testosterone levels of rabbits. J. Environ. Sci. Health B 38 (4), 463-478. 